\title{
AKTYWNOŚĆ SENIORÓW W ŚRODOWISKU LOKALNYM
}

\section{Streszczenie}

Polityka senioralna jawi sięjako istotne wyzwanie wspótczesności. Socjologowie i demografowie ciagle podkreślaja, że społeczeństwo polskie się starzeje. Istnieje zatem wielka potrzeba pobudzenia działań lokalnej polityki społecznej na rzecz seniorów i osób starszych. Celem niniejszego artykułu jest ukazanie aktywności społecznej i edukacyjnej seniorów w społeczności lokalnej. Z powziętej analizy wynika, że seniorzy uczestnicza $w$ zorganizowanych formach aktywności: Uniwersytety Trzeciego Wieku, kluby seniorów, rady seniorów, Caritas parafialne, wolontariat, różne stowarzyszenia i inne organizacje pożytku publicznego Dodać trzeba, że łatwiej jest zaktywizować seniorów zamieszkujacych środowiska miejskie niż środowiska wiejskie. Ponadto $w$ niniejszym artykule ukazano też role pracownika socjalnego jako lidera-moderatora społeczności lokalnej odpowiedzialnego za stymulowanie aktywności spolecznej i edukacyjnej seniorów.

Słowa kluczowe: polityka senioralna, senior, aktywność społeczna i edukacyjna, samorzad terytorialny, środowisko lokalne, pracownik socjalny.

\section{Wstęp}

Polityka senioralna jawi się jako istotne wyzwanie współczesności. Socjologowie i demografowie ciągle podkreślają, że społeczeństwo polskie się starzeje ${ }^{1}$. Istnieje

* Ks. Józef Młyński - dr, adiunkt na Wydziale Studiów nad Rodziną Uniwersytetu Kardynała Stefana Wyszyńskiego w Warszawie.

1 „Starość jest wymiarem niejednolitym, trwającym aktualnie tak długo, jak wiek średni. Dlatego też w populacji osób starych wyróżnia się kilka grup wiekowych: „młodych”, 
zatem wielka potrzeba pobudzenia działań lokalnej polityki społecznej na rzecz seniorów i osób starszych. Zagospodarowanie ich fizyczno-duchowe przez sektor lokalnej polityki to nie tylko próba docenienia tej kategorii ludzi, ale przede wszystkim to troska o ich sytuację: egzystencjalną, rozwojową, oraz psychofizyczną².

Nie ulega wątpliwości, iż pierwszym zadaniem instytucji polityki społecznej jest pobudzenie seniorów do aktywności społecznej i edukacyjnej. Trzeba bowiem obalić mit seniora, staruszka: zmęczonego, wypalonego, niepotrzebnego. Każdy etap życia może być nośnikiem trudności, problemów, strat, porażek i sukcesów. Można być młodym, a przyjmować zachowania starca, ale można też być seniorem, a w konsekwencji cieszyć się życiem, aktywnie żyć, angażować się w różne formy społecznej aktywizacji, dawać z siebie tyle ile to możliwe.

Środowisko lokalne często rozumiane jest jako środowisko społeczne lub społeczność lokalna. Pojęć tych nie cechują ściśle określone znaczenia. Ich jednak wspólnym mianownikiem jest otoczenie społeczne jednostki oraz zbiorowości zamieszkujących określone terytorium. Środowisko lokalne to „grupa ludzi zamieszkujących ograniczone i względnie izolowane terytorium, posiadających i ceniących wspólną tradycję, wartości, symbole, instytucje usługowe i kulturowe, świadomych jedności, odrębności i gotowości do wspólnego działania, żyjących w poczuciu przynależności i wewnętrznego bezpieczeństwa"3.

Miejscem realizacji polityki senioralnej w środowisku zamieszkania są samorządy terytorialne. Samorząd terytorialny to przede wszystkim wspólnota mieszkańców w danym regionie państwa, którą wyróżnia świadomość wspólnoty, wspólne cele, wspólny los, utworzona z mocy prawa oraz realizująca działania wynikające z mocy potrzeb mieszkańców. Istotą samorządu jest zarządzanie sprawami lokalnymi przez jego obywateli ${ }^{4}$.

w wieku pomiędzy 65 a 75 rokiem życia, „starych”, w wieku 75-85 lat, i „,bardzo starych”powyżej 85 lat”. T. Parnowski, Jak się starzejemy? Wymiar biologiczny procesu starzenia się, w: Edukacja osób starszych. Uwarunkowania, trendy, metody, red. K. Lipka-Szostak, Warszawa 2013, s. 9.

2 Lokalna polityka społeczna, kreowana i realizowana przez jednostki samorządu terytorialnego zarówno w skali lokalnej, jak i regionalnej, stanowi istotny element polityki społecznej w państwie, a w niektórych sferach, jedyny sposób wpływania na sytuację mieszkańców danego terenu, w tym również seniorów będących jej podmiotem. E. Kulesza, Lokalna polityka społeczna, Warszawa 2014, s. 5.

3 T. Pilch, Środowisko lokalne - struktura, funkcje, przemiany, w: Pedagogika spoŁeczna, red. T. Pilch, I. Lepalczyk, Warszawa 1995, s. 157.

4 Por. W. Lis, Istota i rola samorzadu terytorialnego w państwie demokratycznym, „Roczniki Nauk Prawnych” 2012, nr 1, s. 161-162. 
Celem niniejszego artykułu jest ukazanie potrzeby aktywności seniorów na poziomie społecznym i edukacyjnym w środowisku ich zamieszkania oraz podkreślenie roli pracownika socjalnego zajmującego się animacją społeczną seniorów. Wypada dodać, że misja samorządów terytorialnych odpowiedzialnych za kształtowanie polityki społecznej wobec seniorów jawi się jako signum temporis współczesności.

\section{Aktywność społeczna}

Podstawowym czynnikiem implikującym aktywność społeczną seniorów jest ich stan zdrowia. Zdrowie bowiem warunkuje prawidłowe funkcjonowanie jednostki w środowisku zamieszkania, jej samodzielne zaspokajanie potrzeb oraz rozwój bio-psycho-społeczny. Aktywność to także sposób komunikacji międzyosobowej w relacji do innych ludzi i środowiska otaczającego ich świat. Ważny również jest dobrostan psychiczny seniorów, który z kolei wpływa na filozofię życia człowieka, jej system zachowania, preferowanych wartości będących efektem udanego życia.

Zwykło się powtarzać sentencję - w zdrowym ciele zdrowy duch. Sentencja ta istotnie koreluje $\mathrm{z}$ formami funkcjonowania i postępowania seniorów. W literaturze aktywność rozpatruje się na trzech poziomach: formalnym, nieformalnym i samotnym. Aktywność formalna dotyczy szerokiego zaangażowania się seniorów w sieci społeczne (stowarzyszenia, koła pomocowe, wolontariat), w zakres polityki, pracę na rzecz środowiska lokalnego i inne formy aktywności (wycieczki) współpracy międzyludzkiej. Poziom aktywności nieformalnej zawęża się do kręgu najbliższej rodziny, kręgu przyjaciół, grupy dobrych sąsiadów. Ich formy zachowania i spędzania wspólnego czasu wyznaczają im rytm życia. Samotność z kolei jako aktywność (chociaż trudno samotność nazwać aktywnością, która zwykle jest współdziałaniem względem innych osób) ogniskuje się wokół osobistych form spędzania czasu przez seniorów. I zwykle obejmuje oglądanie telewizji, czytanie, rozwijanie własnych zainteresowań lub realizację marzeń z młodzieńczych lat ${ }^{5}$.

W literaturze można odnaleźć wiele informacji na temat typologii aktywności seniorów, którą należy aplikować do środowiska lokalnego. A. Kamiński ukazuje dwa jej zakresy: pracy i zainteresowania.

a. pierwszy łączy się z wykonywaniem pracy cenionej i użytecznej - to kontynuacja zatrudnienia, pełnienie odpowiedzialnego stanowiska, połączenie

5 Por. B. Szatur-Jaworska, P. Błędowski, M. Dzięgielewska, Podstawy gerontologii społecznej, Warszawa 2006, s. 161. 
pracy z wypoczynkiem, odgrywanie określonych ról społecznych (polityka), działania na rzecz rodziny w formie opiekuńczej i usługowej;

b. drugi zakres aktywności seniorów ogniskuje się wokół ich zainteresowań - szeroko rozumiane czytelnictwo, uprawianie sportu, życie związane z kulturą rozwoju (wykłady, prelekcje, nauka, zwiedzanie).

c. istnieją jeszcze seniorzy, którzy tworzą zakres aktywności religijnej - to grupa osób, dla których najcelniejszym jest codzienna eucharystia, uczestnictwo w grupach wspólnotowych, kręgach biblijnych, grupy różańcowe, wspólna modlitwa, słuchanie mediów religijnych.

Do koncepcji A. Kamińskiego należałoby dodać zakres: pomoc najbliższym lub obcym - dotyczy to opieki nad wnukami, lub całkowite wychowywanie wnuków w sytuacji, gdy rodzice uczestniczą w procesie migracji zarobkowej, opieka nad osobą starszą, czyli jeszcze seniorzy zajmują się wsparciem osób starszych wewnątrz kraju lub nawet poza krajem.

Podobną koncepcję aktywności seniorów nieco bardziej rozszerzoną i skategoryzowaną prezentuje G. Orzechowska. Wymienia bowiem siedem rodzajów aktywności: domowo-rodzinną (np. prowadzenie gospodarstwa domowego), kulturalną (określa szczególnie miejski styl życia i dotyczy czytania, oglądania telewizji, korzystania z instytucji kulturalnych), zawodową (dotyczy zaspokojenia jeszcze użyteczności seniora, jego przydatności, pełnienia pozycji społecznej, posiadania określonego statusu społecznego), społeczna (zaangażowanie społeczne, podejmowanie różnych akcji społecznych nawet czasem bez wynagrodzenia ekonomicznego, typowy działacz społecznik), edukacyjną (dalsze szkolenie, doskonalenia własnych umiejętności - komputer, portale społecznościowe, poznawanie nowych zagadnień), religijną (bilansowanie życia, uczestnictwo w obrzędach religijnych, angażowanie się w różne grupy i wspólnoty, poświęcenie więcej czasu dla Boga), relaksacyjną (podejmowanie nowych form relaksacji wyrażających się w ruchu fizycznym, ale też w różnych formach wypoczynku turystycznego lub fizycznej pracy na działce) ${ }^{7}$.

Według J. Semkowa „do najważniejszych form aktywności społecznej seniorów należy ich zaangażowanie w sprawy lokalnej społeczności oraz w działania różnych organizacji, np. upowszechniających wiedzę, hobbystycznych, religijnych"s.

\footnotetext{
6 Por. A. Kamiński, Studia i szkice pedagogiczne, Warszawa 1978, s. 259-365.

7 Por. G. Orzechowska, Aktualne problemy gerontologii społecznej, Olsztyn 1999,
} s. 28-29.

8 Por. J. Semków, Niektóre problemy aktywności społeczno-kulturalnej w okresie późnej dorosłości, w: Aktywność społeczna, kulturalna i oświatowa seniorów, red. A. Fabiś, Bielsko-Biała 2008, s. 18. Zagadnienie aktywności społecznej w środowisku lokalnym 
Aktywność tej grupy społecznej na poziomie lokalnym ogniskuje się m.in. wokół organizacji pozarządowych, wolontariatu oraz współpracy z organizacjami samorządu lokalnego. Odwołując się do powyżej wskazanego podziału aktywności na nieformalną i formalną wydaje się uznać, iż aktywność nieformalna na rzecz rodziny i środowiska podyktowana jest doraźnymi potrzebami rodziny lub otoczenia i zwykle ulega zmianom w tempie zmian zachodzących w rodzinie i społeczeństwie. $Z$ kolei aktywność formalna jest udziałem seniorów skupiających się i aktywnie działających $w$ różnych organizacjach społecznych. $Z$ diagnozy przeprowadzonej przez J. Czapińskiego i P. Błędowskiego w roku 2013 wynika, że proporcja aktywnie działających seniorów i seniorek w środowisku lokalnym jest zróżnicowania i zależy w dużej mierze od cech indywidualnych. Do męskich aktywności zaliczają się szczególnie organizacje typu: partie polityczne, kluby sportowe, władze samorządowe i koła zainteresowań (np. myśliwskie, motoryzacyjne, czy wędkarskie), natomiast do damskich środki wsparcia i organizacje pomocowe, towarzyskie, religijne, komitety mieszkańców oraz organizacje upowszechniające wiedzę ${ }^{9}$ (zob. wykres 1).

Aktywizacja społeczna seniorów wpływająca bezpośrednio na jakość ich życia koreluje z jej celami i funkcjami. Literatura gerontologiczna określa kilka funkcji aktywności seniorów, m.in.: funkcję adaptacyjną, funkcję integracyjną, funkcję kompensacyjną, funkcję kształcąca, funkcję rekreacyjno-rozrywkową, funkcję psychogeniczną. Wypadałoby dodać jeszcze funkcję religijno-moralną, opiekuńczą i wspierającą oraz asymilacyjną ${ }^{10}$. Natomiast według H. Mogielnickiej do funkcji i celów seniorów uczestniczących w aktywności społecznej należy zaliczyć: utrzymanie sprawności fizycznej i zdrowotnej, usamodzielnienie się seniora, pobudzenie seniora do zaradności, uczenie współdziałania w grupie, wpływanie na kontakty i relacje międzyosobowe, przygotowanie do współżycia międzyludzkiego w środowisku egzystencji, uczczenie umiejętności spędzania czasu z osobami bliskimi, z sąsiadami, kształtowanie sensu życia - bycia potrzebnych dla innych, rozwijanie zainteresowań, rozwijanie osobowości ${ }^{11}$.

opisuje także P. Błędowski. P. Błędowski, Lokalna polityka społeczna wobec ludzi starych, Warszawa 2002.

9 J. Czapiński, P. Błędowski, Aktywność społeczna osób starszych w kontekście percepcji Polaków, Warszawa 2014, s. 69.

10 Por. B. Szatur-Jaworska, P. Błędowski, M. Dzięgielewska, Podstawy gerontologii..., dz. cyt., s. 164.

11 Por. A. Chabior, Aktywność i aktywizacja osób starszych, w: Starzenie się i starość w perspektywie pracy socjalnej, red. A. Chabior, A. Fabiś, J. K. Wawrzyniak, Warszawa 2014, s. 80 . 


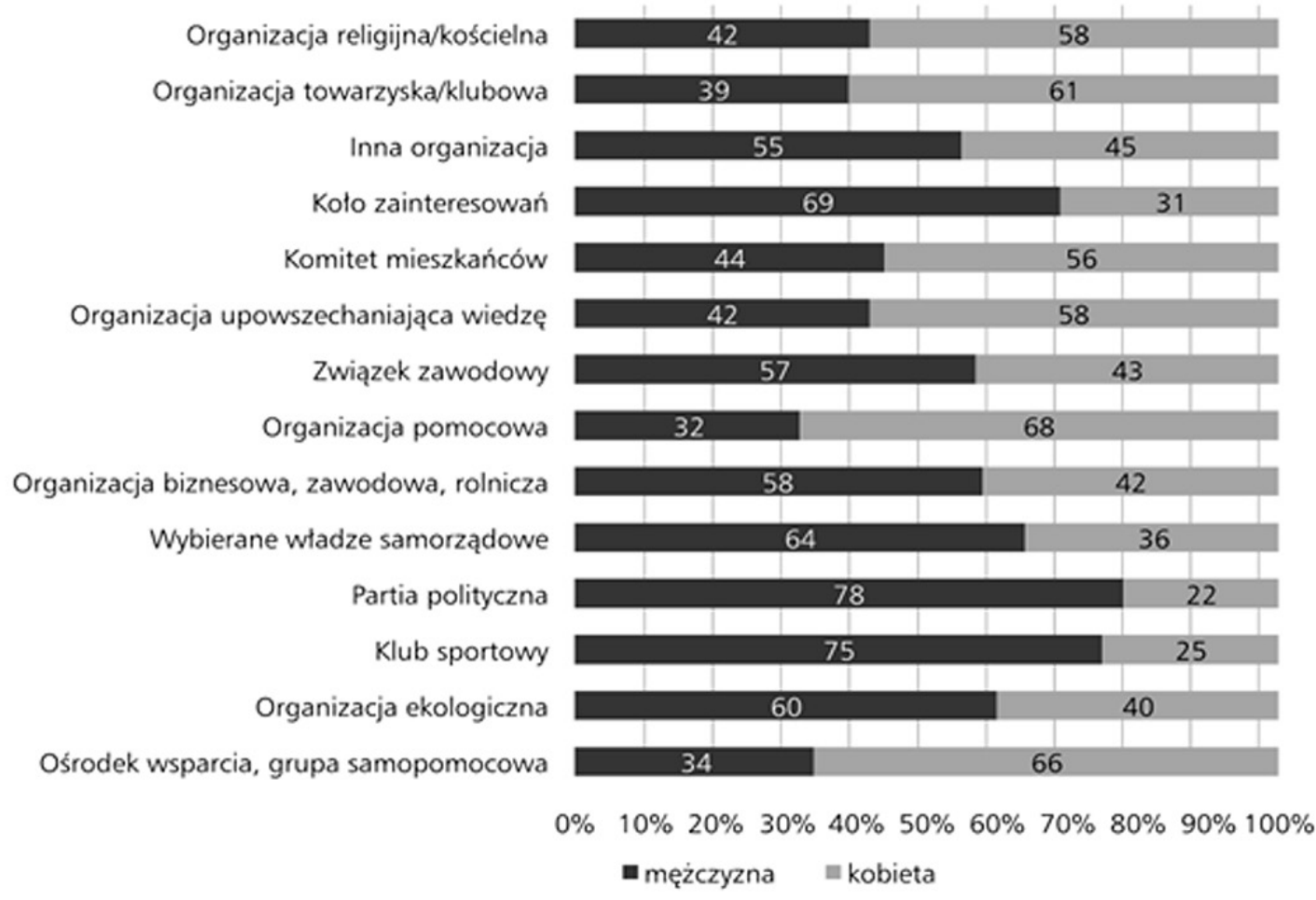

Wykres 1. Proporcja kobiet i mężczyzn wśród seniorów działających w różnych rodzajach organizacji

Źródło: Aktywność społeczna osób starszych w kontekście percepcji Polaków, Warszawa 2014, s. 70 .

Nie ulega wątpliwości, że aktywność jako najcelniejszy aspekt egzystencji osób 60+ ściśle koreluje z jakością życia, poczuciem satysfakcji, zadowolenia, szczęścia i zdrowia. Każdy człowiek, również w późniejszym okresie chce być użyteczny i pożyteczny. Nie można skazać go na samotne życie w tłumie. Należy docenić podmiotowość seniora aktywnie żyjącego w środowisku lokalnym. Podmiotowość ta domaga się, jak zaznaczał K. Wojtyła „W miarę jak narasta potrzeba zrozumienia człowieka jako jedynej w sobie i niepowtarzalnej osoby, zwłaszcza zaś - w całym tym właściwym człowiekowi dynamizmie działania (czynu) i dziania się - potrzeba zrozumienia osobowej podmiotowości człowieka, kategoria przeżycia uzyskuje swoje znaczenie [...]. Chodzi bowiem nie tylko o metafizyczną obiektywizację człowieka jako podmiotu działającego, czyli sprawcy swoich czynów, ale chodzi o ukazanie osoby jako podmiotu przeżywającego swoje czyny, swoje doznania, a w tym wszystkim swoją podmiotowość"’12.

Każdy człowiek mimo upływu czasu i wieku pozostaje istotą twórczą i może wnieść w rozwój każdej społeczności wiele dobrych i cennych inicjatyw. Również

12 K. Wojtyła, Osoba i czyn oraz inne studia antropologiczne, Lublin 2000, s. 439. 
seniorzy odznaczający się doświadczeniem, zdobytymi umiejętnościami i kompetencjami są bardzo ważnym ogniwem w tkance społecznej. W swoim życiu kierują się zasadami: aktywności, decyzji oraz woli. Aktywność przejawia się w ich formach zachowania, rozwoju osobowości. Decyzja jest aspektem podjęcia aktywności wprowadzających ich $\mathrm{w}$ działanie. Natomiast wola to element realizacji podjętych działań, które są trafnie dobrane oraz odpowiadają możliwościom i skuteczności realizacji siebie. Wydaje się zatem, że aktywność seniorów nastawiona na rozwój siebie przynosi pożądane efekty w każdym środowisku lokalnym.

\section{Aktywność edukacyjna}

Edukacja to ogół procesów i oddziaływań warunkujących rozwój każdego człowieka. Podmiotem tego procesu są dzieci, młodzież, studenci. Trudno jednak byłoby zawęzić edukację jedynie do tej kategorii osób. Powszechnie wiadomo, że każdy z nas uczy się do końca życia. Również seniorzy uczestniczą w klasycznej edukacji, która polega na opanowaniu i przyswojeniu danej wiedzy o otaczającym świecie, doskonalenie umiejętności podejmowania czynów, które podnoszą sprawność funkcjonowania człowieka ${ }^{13}$. W ten rodzaj edukacji wpisuje się gerontologia jako nauka o starości zdążająca do wyjaśnienia złożonej istoty procesu starzenia się człowieka w wymiarze: biologicznym, psychicznym, medycznym, ekonomicznym, społecznym, a nawet duchowym.

Edukacja osób starszych obejmuje różne formy wiedzy, kształtuje umiejętności oraz postawy seniorów wpływające na ich rozwój fizyczny oraz jakość życia. Seniorzy potrzebują zatem kształcenia ustawicznego, które charakteryzuje się permanentnym i twórczym podejściem do życia, udoskonala i ulepsza warunki egzystencji bazując również na doświadczeniach osób starszych. W kalejdoskop aktywności edukacyjnej seniorów wpisują się: Uniwersytety Trzeciego Wieku, Kluby Seniora, Rady Osiedlowe, stowarzyszenia społeczne i inne ${ }^{14}$.

\section{Uniwersytety Trzeciego Wieku}

Historia powstania Uniwersytetów Trzeciego Wieku sięga poprzedniego wieku, a ich ojczyzną jest Francja. W tym bowiem czasie, w 1973 r. przy uniwersytecie

\footnotetext{
13 Por. M.K. Stasiak, Podmiotowy model pracy socjalnej, Łódź 2009, s. 93.

14 Warto zaznaczyć, że Uniwersytety Trzeciego Wieku, Kluby Seniora, Rady Osiedlowe, Stowarzyszenia społeczne są domeną seniorów zamieszkujących obszary miejskie. Na obszarach wiejskich poza Klubami Seniorów, Dziennymi Domami Pomocy seniorzy tworzą różne koła, np. Koło Gospodyń Wiejskich.
} 
w Tuluzie powołano do istnienia pierwszą placówkę dydaktyczną dla seniorów, a jej twórcą był francuski socjolog prof. Pierre Vellas, który mając na uwadze osoby w wieku senioralnym zauważył, że ich doświadczenie życiowe, zdobyte umiejętności i kompetencje życia korzystnie wpływają na wspólnotę bytowania młodych generacji osób. Ponadto chciał skompensować ich niemożność uzyskania wykształcenia w młodym wieku w skutek różnych uwarunkowań społecznych oraz spełnić ich marzenia dotyczące studiowania połączonego z pasją i zainteresowaniami ${ }^{15}$.

Z tego też powodu w 1972 roku prof. Pierre Vellas zorganizował eksperymentalną szkołę letnią dla emerytowanych mieszkańców Tuluzy, która nie tylko cieszyła się wielkim zainteresowaniem, ale stała się sukcesem pracy z osobami starszymi. Podstawowym zadaniem uniwersytetu była troska o psychiczny, umysłowy i fizyczny rozwój osób starszych. Jeszce innym czynnikiem powstania tej placówki dydaktycznej było „,wzrost średniej długości życia ludzkiego, a przede wszystkim wzrost populacji osób starszych, które nie pracują zawodowo, szybkie przemiany cywilizacyjne, które sprawiają, że osoby starsze czują się zagubione i bezradne, potrzeba rozumienia współczesnego świata, dostosowanie do przemian"16.

Obok Stanów Zjednoczonych, Wielkiej Brytanii i Niemiec również w Polsce Uniwersytety Trzeciego Wieku mają swoją odrębną historię. Na terenie naszego kraju pierwszy UTW został alokowany w 1975 roku z inicjatywy prof. Heleny

15 Należy jednak wspomnieć, że zagadnienie starzenia się ludzi było przedmiotem zainteresowań w początkach XX wieku. Do ważniejszych wydarzeń związanych z rozwojem gerontologii na świecie i w Polsce można zaliczyć: 1928 - powstanie pierwszego instytutu gerontologicznego: Stany Zjednoczone, Stanford University w Kalifornii; 1946 - ukazanie się pierwszego naukowego czasopisma gerontologicznego „Journal of Gerontology” (Stany Zjednoczone); 1950 - pierwszy międzynarodowy kongres gerontologiczny (Liege) i powstanie Międzynarodowego Towarzystwa Gerontologicznego; 1959 - ukazanie się książki Edwarda Rosseta Proces starzenia się ludności. Studium demograficzne, będącej pionierską polską publikacją z zakresu demografii gerontologicznej; 1960 - pierwsze ogólnopolskie gerontologiczne badanie ankietowe Sprawy ludzi w wieku emerytalnym (autor: H. Stasiak, OBOP, Warszawa); 1966-1968 - zespół badawczy Instytutu Gospodarstwa Społecznego SGPiS (obecnie SGH) pod kierunkiem prof. Jerzego Piotrowskiego przeprowadza ogólnopolskie badania socjologiczne na temat sytuacji społeczno-ekonomicznej i zdrowotnej ludzi starych w Polsce; 1972 - powstanie Polskiego Towarzystwa Gerontologicznego; 1974 - I Zjazd Naukowy Polskiego Towarzystwa Gerontologicznego; 1974 - utworzenie w Stanach Zjednoczonych Narodowego Instytutu Gerontologicznego (National Institut of Gerontology), kontynuującego działalność placówek badawczych utworzonych bezpośrednio po II wojnie światowej. B. Szatur-Jaworska, P. Błędowski, M. Dzięgielewska, Podstawy gerontologii..., dz. cyt., s. 15.

16 S. Steuden, Psychologia starzenia się i starości, Warszawa 2011, s. 93. 
Szwarc. Bezpośrednią inspiracją było jej spotkanie ze światowym prekursorem, wspomnianym już P. Vellasem. Jak wspomina A. Błachnio, już w 1975 roku, po spotkaniu prof. Heleny Szwarc z prof. P. Vellasem powołano pierwszy polski Uniwersytet Trzeciego Wieku przy Centrum Medycznym Kształcenia Podyplomowego w Warszawie, zaś w roku 1981 powołano Sekcję Uniwersytetów Trzeciego Wieku, które zakładano kolejno we Wrocławiu, Szczecinie, Opolu, Łodzi, Lublinie ${ }^{17}$.

Obecnie w Polsce jest coraz więcej UTW, których celem jest sprawienie, aby czas starości był okresem pełnego życia, realizacji wszelkich zamierzeń, w których osoba się realizuje, a nawet czasem zmienia swoje podejście do świata, do ludzi, społeczeństwa, aby obudzić w sobie ducha współczesności i być potrzebnym i aktywnym dla siebie i innych. Takie ukierunkowanie UTW powinno być przeniknięte duchem personalizmu, gdyż podmiotem tej instytucji jest człowiek. Człowieka zaś, jak stwierdza J. Mazur, nie można traktować jako idei, czy koncepcji, lecz należy pochylać się nad nim z troską, również gdy chodzi o seniorów będących ikonami życia społecznego ${ }^{18}$.

Uniwersytety Trzeciego Wieku, jak każda instytucja edukacyjna, charakteryzują się pewnymi celami. W literaturze przedmiotu wielu autorów gerontologii społecznej wskazuje na następujące cele: włączenie seniorów do systemu kształcenia ustawicznego, aktywizacja osób starszych na poziomie intelektualnym, psychicznym i fizycznym, wdrażanie profilaktyki gerontologicznej, prowadzenie badań naukowych w zakresie gerontologii; rozwój osobowości słuchaczy, poprawa ich jakości życia; tworzenie wspólnie warunków „dobrego starzenia się” oraz pobudzanie seniorów do kontaktów z osobami o podobnych aspiracjach i zainteresowaniach"19.

Trzeba też zaznaczyć, że UTW pełnią wiele funkcji, a szczególnie dwie: edukacyjną i rekreacyjno-integracyjną. Funkcja edukacyjna pogłębia światopogląd człowieka, uczy mądrego gospodarowania czasem, zaspokaja potrzeby poznawcze, integracyjne, poszerza horyzonty umysłowe. Funkcja rekreacyjno-integracyjna uczy budowania więzi przyjaźni, solidarności na poziomie rodzinnym, międzypokoleniowym, narodowym, a szczególnie w najbliższym środowisku zamieszkania. Funkcje te wpływają na poszerzanie kręgu znajomych, zabezpieczają przed

17 Por. A. Błachnio, Starość non profit, Wolontariat na Uniwersytetach Trzeciego Wieku w Polsce i na świecie, Bydgoszcz 2012, s. 90-91.

18 Por. J. Mazur, Duch pracy socjalnej w kontekście pytania o człowieka, w: Współczesne wyzwania i metody pracy socjalnej, red. W. Szymczak, Lublin 2009, s. 14.

19 Por, B. Szatur-Jaworska, P. Błędowski, M. Dzięgielewska, Podstawy gerontologii..., dz. cyt., s. 172. Por. A. Leszczyńska-Rejchert, Człowiek starszy i jego wspomaganie w strone pedagogiki starości, Olsztyn 2007, s. 171. 
poczuciem apatii, osamotnienia. Są istotnym czynnikiem wsparcia seniorów po stracie bliskich. Wypada dodać, jak konstatuje T. Aleksander, dzięki nim osoby starsze ,poszerzają swoje zainteresowania intelektualne, kształtują siły umysłowe i utrwalają motywacje poznawcze" ${ }^{20}$. Ponadto UTW realizują też funkcję profilaktyczną, która wydaje się być najistotniejszą. Działania profilaktyczne na rzecz seniorów to budowanie aktywności społecznej, przeciwdziałanie ich bezradności, nudzie, apatii, alienacji, monotonii, wycofaniu z życia społecznego, a nawet wykluczenia. Szczególnie w środowiskach lokalnych, w których seniorzy i osoby starsze tworzą pewien rodzaj enklawy. Potrzeba zatem budzenia działań integracyjnych z młodszym pokoleniem. Każdy z nas potrzebuje obecności innych ludzi, nie tylko ze względu na brak samowystarczalności, ale z uwagi na konieczność kontaktu, szczególnie z młodym pokoleniem. Dlatego niezwykle potrzebne są kontakty i spotkania dwóch pokoleń: wstępującego i odchodzącego. Szczery i autentyczny dialog generacji wpływa pozytywnie zarówno na rozwój międzyosobowy, aksjologiczny, jak i całe otoczenie społeczne ${ }^{21}$.

Samorządy lokalne przygotowują projekty, których celem jest aktywizowanie seniorów na rzecz społeczności lokalnej. Projekty te realizowane są w ramach zajęć prowadzonych na UTW. Dotyczą zasad integracji grupy, diagnozy potrzeb społeczności lokalnej, prowadzenia różnych akcji i spotkań w przestrzeni miejskiej i wiejskiej, komunikacji, współpracy zespołowej, chęci do działania wolontariackiego i społecznego zaangażowania. Ponadto podejmowane są działania współpracy z domami kultury, przedszkolami, ośrodkami opieki społecznej. Jest to także szansa na wykształcenie liderów środowiskowych.

\section{Instytucje służące aktywności edukacyjnej seniorów}

W ramach struktur sieci społecznej, również na poziomie samorządowym, istnieje wiele innych instytucji o profilu edukacyjno-aktywizującym. Zalicza się do nich: domy pomocy społecznej, Kluby Seniora, Rady Osiedlowe (Gminne), parafialne oddziały Caritas.

Pierwszą instytucją związaną z osobami starszymi są domy pomocy społecznej22, w których realizowane są działania pomocowe dla osób starszych, często schorowanych. W domach tych zaspokajane są ich potrzeby bytowe, ale też edukacyjne, społeczne, oraz religijne. Zwykle w tego typu placówkach umieszcza się

20 T. Aleksander, Andragogika, Radom-Kraków 2013, s. 306.

21 Por. A. Zych, Człowiek wobec starości, Katowice 1999, s. 62.

22 Zgodnie z ustawą o pomocy społecznej z 12 marca 2004 roku DPS-y prowadzą jednostki samorządu terytorialnego. 
osoby, które z różnych przyczyn nie mogą funkcjonować w środowisku rodzinnym; samotny rodzic, opuszczona babcia, przewlekła choroba, brak właściwej opieki lub inne przyczyny losowe. Chociaż DPS-y tworzą swój własny klimat i wydają się być poza obrębem sieci społecznej to jednak ich rola jest bardzo ważna. Swoim pensjonariuszom (seniorom) umożliwiają rozwój kulturowy i społeczny, pomagają $\mathrm{w}$ adaptacji do życia $\mathrm{w}$ placówce i podtrzymywaniu kontaktów z rodziną, prowadzą terapię psychologiczną, terapię przez pracę, arteterapię, muzykoterapię, choreoterapię, rozwijanie swojego hobby, oraz szeroki wachlarz różnych zajęć rekreacyjnych (spacery, wyjścia do lasu, do kina, teatru itp.). Ważnym elementem wsparcia i pomocy seniorom jest współpraca z parafiami na odcinku pomocy religijnej, duchowej. Wypada dodać, że pensjonariusze DPS mają organizowane spotkania z młodzieżą szkolną, z dziećmi przedszkolnymi, jak również z innymi grupami działającymi w środowisku lokalnym. Ich integracja z otoczeniem, z różnymi pomiotami terytorialnymi jawi się, jako współpraca i aktywizacja społeczna.

Organizacjami zarządzającymi wolnym czasem seniorów są kluby seniora. Zwykle wyróżnia się dwa rodzaje klubów: zakładowe oraz środowiskowe. Jedne i drugie lokowane są w przestrzeni lokalnej miast, osiedli, wiosek. Kluby zakładowe jednak zrzeszają jedynie emerytowanych pracowników, a środowiskowe zrzeszają seniorów z najbliższego środowiska zamieszkania. Są i takie, które zrzeszają emerytów z różnych wiosek i powinny przyjmować nazwę gminne kluby seniora.

Pierwszym celem klubów seniora jest umożliwienie ludziom starszym (seniorom) spędzenia wolnego czasu, zaspokojenie ich potrzeb, wyrwanie z monotonii życia, obudzenie możliwości aktywności fizycznej i społecznej. W ramach spotkań, które zwykle odbywają się cyklicznie w każdym miesiącu, seniorzy uczestniczą w zajęciach typu: aktywność fizyczno-ruchowa, wycieczki krajoznawcze, zabawy taneczne o charakterze integracyjnym, porady i wykłady zdrowotne, profilaktyka chorób cywilizacyjnych, spotkania wykorzystania własnych talentów, edukacja komputerowa i językowa, spotkania duchowe (wieczornice papieskie), spotkania poetyckie, bezpieczeństwo w ruchu drogowym, prowadzenie prac artystycznych i manualnych, wspomnienia historyczne, spotkania patriotyczne. Kluby te pozwalają osobom starszym nie tylko zapomnieć o ich problemach, ale pomagają rozwijać im życie towarzyskie i społeczne. Ponadto aktywność w klubach seniora ułatwia integrację ze środowiskiem lokalnym, nawiązywanie nowych, a także podtrzymywanie dotychczasowych znajomości, usprawnienie, relatywna edukacja oraz wzajemna pomoc ${ }^{23}$.

23 Por. J. K. Wawrzyniak, Instytucje pomocowe $i$ organizacje pozarzadowe $w$ pracy na rzecz osób starszych, w: Starzenie się i starość w perspektywie pracy socjalnej, red. A. Chabior, A. Fabiś, J. K. Wawrzyniak, Warszawa 2014, s. 142. 
Współcześnie, jak podkreślają socjologowie i demografowie, seniorów jest coraz więcej ${ }^{24}$. Seniorzy chcą kształtować swoją przyszłość, wpływać na rozwój polityki senioralnej oraz podejmować wiele działań współmiernych do programów służących dobru mieszkańców. Dlatego potrzeba aktywizacji seniorów wydaje się być bardzo pilna. Pomocną dłoń dla samorządów lokalnych stanowią Rady Seniorów. Rady seniorów to ciała kolegialne o charakterze doradczym, pomocowym i inicjatywnym, które wspierają rady gminy w realizacji polityki senioralnej. Ich zadaniem jest polepszenie warunków i dobrostanu osób starszych oraz promocja działań aktywizujących ${ }^{25}$.

Rady Seniorów jawią się jako partnerskie podmioty wymiany zdań z przedstawicielami samorządu. Samorząd wspierany głosem seniorów lepiej rozeznaje potrzeby swoich obywateli, szczególnie osób starszych, ich problemy, często niezauważane z poziomu administracyjnego. Tym samym dbają o jakość życia seniorów i innych obywateli. Seniorzy zyskują pewność siebie, odzyskują poczucie wartości, czują się odpowiedzialni, pewni siebie, włączają się w społeczne inicjatywy, uczą siebie nawzajem, uczestniczą w dialogu międzypokoleniowym.

Dodać należy, iż w ostatnim czasie ustawą z dnia 11 października 2013 roku o zmianie ustawy o samorządzie gminnym ustawodawca wprowadził możliwość tworzenia w gminach tzw. gminnych rad seniorów. Podobnie jak w przypadku osiedlowych rad seniorów pełnią potrójną funkcję: konsultacyjną, doradczą oraz inicjatywno-aktywizującą ${ }^{26}$.

Trzeba też wspomnieć o parafialnych oddziałach Caritas, które w połączeniu z Akcją Katolicką włączają się w różne formy aktywizacji i edukacji seniorów. Edukacja seniorów realizowana jest na kilku poziomach: intelektualnym w ramach, którego prowadzone są wykłady społeczne, biblijne, patriotyczne; rekreacyjnym poprzez organizowanie wycieczek, pielgrzymek; poradnianym z zakresu zdrowia, wsparcia $\mathrm{w}$ różnych problemach; religijnym w zakresie organizowania różnych

24 Warto dodać, że osoby senioralne stanowią dziś blisko 1/5 populacji, zaś wedle prognoz z GUS do 2050 roku ich liczba w Polsce wzrośnie o 5,4 mln w stosunku do 2013 roku. Zważywszy na współczynnik przyrostu naturalnego osoby starsze będą stanowiły aż 1⁄3 populacji. Por. A. Fiedotow, ABC rad Seniorów, „Polityka Senioralna” 2017, nr 4, s. 7.

25 Chociaż Rady Seniorów nie pełnią bezpośrednio roli edukacyjnej to jednak pośrednio do ich zadań należy inicjowanie aktywności osób starszych, czyli m.in. ,podejmowanie działań zmierzających do wykorzystania potencjału i czasu ludzi starszych na rzecz inicjatyw środowiskowych, w szczególności w zakresie kultury, sportu i edukacji”, http:// www.skierniewice.eu/urzad-miata/miasto/rada-seniorow/ [dostęp 01.06.2018 r.].

26 Por. A. Ganeczko, Rady seniorów w Polsce: podstawa prawna i liczba, „Polityka Senioralna" 2014, nr 4, s. 5. 
nabożeństw, grup modlitewnych; pomocowym poprzez przygotowywanie okolicznościowych paczek dla samotnych i cierpiących osób oraz pomoc dzieciom w zakresie kompensacji edukacyjnych.

W ramach działalności parafialnych oddziałów Caritas realizowane są także działania wolontaryjne. Wolontariat to pozafinansowa chęć służenia innym, szczególnie w środowiskach, w których potrzeby innych ludzi warunkują pragnienie udzielania im wsparcia i pomocy. Definicyjnie, to bezpłatne, świadome i altruistyczne podejmowanie działań na rzecz innych, wykraczających poza obszar wsparcia formalnego (rodzina, przyjaciele) ${ }^{27}$. Parafialne oddziały Caritas to grupa wolontariuszy zaangażowanych w działalność charytatywną w parafii. Ich zadaniem jest m.in. realizowanie i koordynowanie, w miarę możliwości i środków, inicjatyw i zadań związanych z funkcjonowaniem mieszkańców w środowisku lokalnym.

W Polsce idea wolontariatu wciąż zawężona jest do obszarów udzielenia wsparcia i pomocy osobom przewlekle chorym, potrzebującym, dzieciom, niepełnosprawnym. Zawężenie to wydaje się być stereotypowe i bardzo tradycyjne. Tymczasem jak zauważa D. Pietrykowski na świecie pod tym pojęciem „mieszczą się też aktywności sąsiedzkie, kulturalne, sportowe, szkolne"28.

Idea wolontariatu została szeroko rozwinięta w ramach działalności Caritas parafialnej. Działają nie tylko szkolne koła Caritas, ale również w działalność tą angażują się seniorzy. Pod patronatem Caritas aktywnie działają w środowiskach zamieszkania. Angażują się w świetlicach socjoterapeutycznych, poradniach parafialnych, kuchniach dla osób bezdomnych, wspierają rodziny wieloproblemowe. Trzeba dodać, że wspierają się w grupach samopomocowych, sąsiedzkich, często odwiedzają chorych ofiarując im swój wolny czas na wspólną rozmowę oraz pomoc w zakresie czynności domowych.

\section{Rola pracownika socjalnego jako lidera seniorów}

W ramach polityki społecznej, której podmiotem są seniorzy, istnieje wielka potrzeba powołania lidera społeczności lokalnej. W moim przekonaniu funkcję lidera może pełnić pracownik socjalny odpowiednio przygotowany do tej roli. Lider społeczności lokalnej byłby odpowiedzialny za animowanie seniorów by włączali się w sprawy swojego środowiska lokalnego. Jako pełnoprawni obywatele powinni uczestniczyć we wszystkich sektorach polityki społecznej: publicznym, rynkowym oraz pozarządowym, często określanym jako sektor non-profit. Pracownik socjalny

27 Na prawo patrz, red. D. Pietrykowski, Warszawa 2006, s. 3.

28 D. Mól, Kryzys wolontariatu?, „Wolontariat” 2009, nr 5, s. 2. 
w sieci lokalnej pełniłby rolę lidera-moderatora inicjując ich aktywność oraz wykorzystują kapitał intelektualny, fizyczny, kulturowy. Jego działania powinny dotyczyć, zgodnie z typem polityki społecznej usług interwencyjnych scedowanych na osoby niewydolne ekonomicznie i przejawiające trudną sytuację życiową oraz usług optymalnych wiążących się z zaspokojeniem potrzeb seniorów.

Pracownik socjalny jako animator społeczny pełniłby rolę związaną z procesem zarządzania dostępnymi usługami w środowisku lokalnym. Jest rzecznikiem, mediatorem i koordynatorem. Występując z ramienia samorządu lokalnego dobrze zna potrzeby seniorów, ich zasoby zewnętrzne. Jako zaś lider-moderator może aktywnie prowadzić wiele przedsięwzięć z seniorami i dla seniorów. Jego działania powinny być ukierunkowane wieloaspektowo: rozeznania potrzeb seniorów, podejmowanie inicjatyw społecznych, podejmowanie inicjatyw edukacyjnych, kreator wolnego czasu, współpraca z podmiotami samorządowymi, podejmowanie innowacyjnych działań, tworzenie przyjaznych projektów, motywowanie seniorów do wspólnych działań kulturowych.

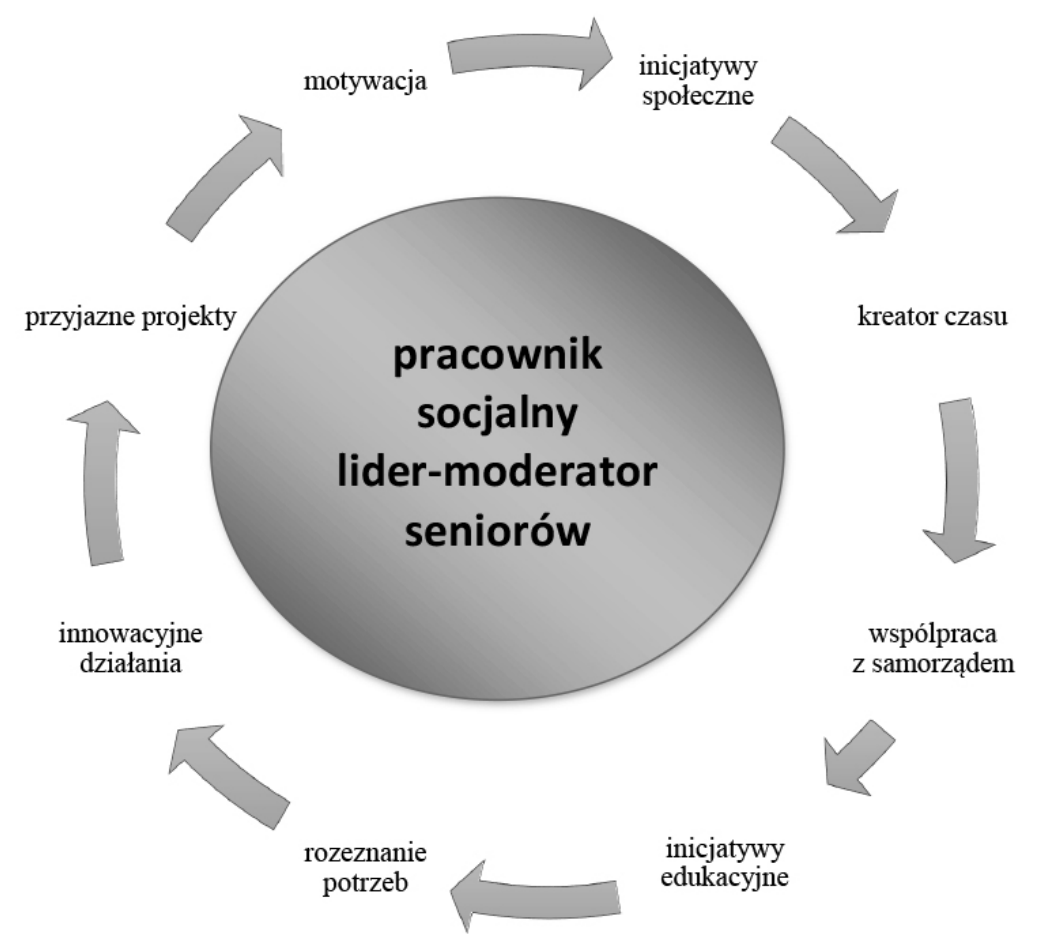

Rysunek 1. Pracownik socjalny jako lider seniorów w społeczności lokalnej

Źródło: opracowanie własne

W ramach edukacyjnych działań na rzecz osób seniorów pracownik socjalny (lider-moderator) organizowałby strategiczne zarządzanie w lokalnym środowisku. Te inicjatywy są ze wszech miar bardzo ważne. $Z$ jednej strony pozwalają 
obiektywnie i integralnie dostrzec zapotrzebowania seniorów, z drugiej zaś, kierując się zasadą lokalności dostrzec ich trudności, problemy oraz potrzeby. W tym kontekście planowanie strategiczne będące częścią zarządzania strategicznego organizowane jest na trzech poziomach: strategicznym, taktycznym i działaniach operacyjnych. Podejście strategiczne to długofalowy proces systematycznej współpracy z seniorami, nastawiony na dążenie do realizacji określonej ich wizji przyszłości zarówno w aspekcie aktywności społecznej i edukacyjnej. Według J. Przywojskiej ,jest to długofalowa koncepcja, stanowiąca podstawę realizacji przyjętych wzorców interwencji społecznych, podejmowanych w celu poprawy zjawisk występujących w obrębie danej społeczności" ${ }^{29}$. Kompetentne ustalenie celów długoterminowych wymaga systematycznej obserwacji i oceny zmian zachodzących w zbiorowości ludzi starszych. Cele te w dużej mierze zależą od tego, czy pracownik socjalny podejmuje pracę z seniorami w środowisku miejskim czy wiejskim. Należy dodać, że w środowisku wiejskim pracownik socjalny musi uwzględnić rozproszenie przestrzenne. Odległość od gospodarstw domowych, trudny teren, niestandardowe budynki to tylko niektóre czynniki, z którymi trzeba się zmierzyć. W tym kontekście konieczna jest pomoc sąsiedzka i stworzenie właściwego klimatu społecznego dla osób starszych ${ }^{30}$.

Istotnym elementem działań społecznych jest wspomaganie seniorów w zakresie wszelkich działań, a szczególnie: stymulowanie ich aktywności i pobudzanie do odpowiedzialności za kształt oraz jakość życia osób starszych, koncentracja na ich rozwoju i potencjale, odkrywanie i wyzwalanie społecznych sił seniorów, zapobieganie bierności przez aktywowanie wsparcia społecznego, zapobieganie samotności przez aktywność edukacyjną i ruchową, budowanie atrakcyjnej i szerokiej oferty dla wykorzystania ich czasu wolnego ${ }^{31}$.

Pracownik socjalny jako lider-moderator polityki senioralnej obok kompetencji i posiadanych umiejętności powinien być: przyjacielem, towarzyszem życia, empatycznym doradcą. Te cechy wpływają na zaufanie, szczerość, jakość kontaktu i prowadzonych usług. O wiele łatwiej prowadzi się różne działania, gdy lidera cechuje osobowość otwarta, życzliwa. Osoba sympatyczna i empatyczna posiada wrodzoną lub nabytą zdolność do empatii32. Empatia zaś pozwala współpracować

\footnotetext{
29 Tamże, s. 88.

30 Por. B. Szatur-Jaworska, P. Błędowski, M. Dzięgielewska, Podstawy gerontologii..., dz. cyt., s. 318.

31 Por. A. Leszczyńska-Rajchel, Człowiek starszy i jego wspomaganie $-w$ strone pedagogiki starości, Olsztyn, s. 206-209.

32 Por. W. Szewczyk, W. Okła, Podstawy poradnictwa rodzinnego, Warszawa 2016, s. 23.
} 
i widzieć wewnętrzne potrzeby i dyspozycje osób starszych oraz otwierać przed nimi przestrzeń aktywności społecznej i edukacyjnej.

\section{Zakończenie}

Aktywizowanie społeczne i edukacyjne seniorów to nie tylko ważny obszar działań samorządu lokalnego, ale również istotny aspekt życia seniorów. Trudno bowiem wyobrazić sobie, aby grupa seniorów w pilotce samorządowej została pominięta, skupiając się jedynie na osobach starych i chorych, niewydolnych fizycznie. W tym kontekście należy odwołać się do solidaryzmu społecznego, który zdaniem H. Pescha ,jest tym systemem społecznym, który wychodząc z założeń moralnych ograniczeń struktury życia społecznego, domaga się budowy społeczeństwa na zasadach wzajemnej solidarności i współodpowiedzialności członków danego społeczeństwa. Solidarność to dążenie całej społeczności do wspólnego celu, jakim jest realizacja idei sprawiedliwości społecznej. Jej warunkiem jest budowa organiczna społeczeństwa na gruncie więzi zawodowej z uwzględnieniem czasu i miejsca" 33 , ale również budowa społeczności lokalnych, w których seniorzy maja swoją przestrzeń.

Celem artykułu było ukazanie aktywności społecznej i edukacyjnej seniorów w społeczności lokalnej. Z przeprowadzonej analizy wynika, że aktywność ta jest korzystna i potrzebna. Seniorzy uczestniczą w zorganizowanych formach aktywności: Uniwersytety Trzeciego Wieku, kluby seniorów, rady seniorów, Caritas parafialne, różne stowarzyszenia, wolontariat i inne instytucje pożytku publicznego. Tego rodzaju polityka realizowana w środowiskach lokalnych pozwala dostrzec osoby 60+, organizować im czas, aktywizować intelektualnie, fizycznie i kulturowo, zaspokajać potrzeby. Nadto wykorzystać ich doświadczenie życiowe i angażować w różne społeczne przedsięwzięcia oraz inicjatywy. To rodzaj innowacyjności, w której seniorzy odnajdują swoją przestrzeń. Dodać trzeba, że łatwiej jest zaktywizować seniorów zamieszkujących środowiska miejskie niż środowiska wiejskie.

Również rola pracownika socjalnego jako lidera-moderatora seniorów w społecznościach lokalnych wydaje się być współcześnie ważna. Zważywszy na ciągle wzrastającą liczbę osób w wieku senioralnym potrzeba zarządzania ich kapitałem społecznym to istotny element polityki społecznej. „Byłby to jeden z kluczowych sposobów wypełniania misji pracy socjalnej, jaką jest wywieranie korzystnego

33 C. Strzeszewski, Katolicka nauka społeczna, Warszawa 1985, s. 166. 
wpływu na kształt społeczności lokalnej i poszczególnych jednostek tworzących tę wspólnotę"34, w której seniorzy stanowią integralną grupę społeczną.

\section{Bibliografia}

Aleksander T., Andragogika, Radom-Kraków 2013, s. 306.

Błachnio A., Starość non profit, Wolontariat na Uniwersytetach Trzeciego Wieku w Polsce i na świecie, Bydgoszcz 2012.

Błędowski P., Lokalna polityka społeczna wobec ludzi starych, Warszawa 2002.

Chabior A., Aktywność i aktywizacja osób starszych, w: Starzenie się i starość w perspektywie pracy socjalnej, red. A. Chabior, A. Fabiś, J. K. Wawrzyniak, Warszawa 2014, s. 80-85.

Czapiński J., Błędowski P., Aktywność społeczna osób starszych w kontekście percepcji Polaków, Warszawa 2014.

Fiedotow A., ABC rad Seniorów, „Polityka Senioralna” 2017, nr 4, s. 7.

Ganeczko A., Rady seniorów w Polsce: podstawa prawna i liczba, „Polityka Senioralna" 2014, nr 4, s. 5.

Kamiński A., Studia i szkice pedagogiczne, Warszawa 1978.

Kulesza E., Lokalna polityka społeczna, Warszawa 2014.

Leszczyńska-Rajchel A., Człowiek starszy i jego wspomaganie - w strone pedagogiki starości, Olsztyn, s. 206-209.

Lis W., Istota i rola samorzadu terytorialnego w państwie demokratycznym, „Roczniki Nauk Prawnych” 2012, nr 1, s. 161-181.

Markiewicz Z., O rozumieniu idei wolontariatu, w: Idea wolontariatu w ksztaltowaniu społeczności lokalnych, red. D. Widelak, S. Śliwa, Opole 2009, s. 11-22.

Mazur J., Duch pracy socjalnej w kontekście pytania o człowieka, w: Współczesne wyzwania i metody pracy socjalnej, red. W. Szymczak, Lublin 2009, s. 13-20.

Mól D., Kryzys wolontariatu?, „Wolontariat” 2009, nr 5, s. 2.

Na prawo patrz, red. D. Pietrowski, Warszawa 2006.

Orzechowska G., Aktualne problemy gerontologii społecznej, Olsztyn 1999.

Parnowski T., Jak się starzejemy? Wymiar biologiczny procesu starzenia się, w: Edukacja osób starszych. Uwarunkowania, trendy, metody, red. K. Lipka-Szostak, Warszawa 2013, s. 9-16.

Pilch T., Środowisko lokalne - struktura, funkcje, przemiany, w: Pedagogika społeczna, red. T. Pilch, I. Lepalczyk, Warszawa 1995, s. 155-173.

Przywojska J., Nowe zarzadzanie i governance w pracy socjalnej, Warszawa 2014.

34 Z. Markiewicz, Orozumieniu idei wolontariatu, w: Idea wolontariatu w kształtowaniu społeczności lokalnych, red. D. Widelak, S. Śliwa, Opole 2009, s. 19. 
Semków J., Niektóre problemy aktywności społeczno-kulturalnej w okresie późnej dorosłości, w: Aktywność społeczna, kulturalna i oświatowa seniorów, red. A. Fabiś, Bielsko-Biała 2008, 17-22.

Stasiak M.K., Podmiotowy model pracy socjalnej, Łódź 2009.

Steuden S., Psychologia starzenia się i starości, Warszawa 2011.

Strzeszewski C., Katolicka nauka społeczna, Warszawa 1985.

Szatur-Jaworska B., Błędowski P., Dzięgielewska M., Podstawy gerontologii spotecznej, Warszawa 2006.

Szewczyk W., Okła W., Podstawy poradnictwa rodzinnego, Warszawa 2016.

Ustawa o pomocy społecznej z 12 marca 2004 roku, Dz.U. 2004 nr 64, poz. 593.

Wawrzyniak J.K., Instytucje pomocowe i organizacje pozarzadowe $w$ pracy na rzecz osób starszych, w: Starzenie się i starość w perspektywie pracy socjalnej, red. A. Chabior, A. Fabiś, J.K. Wawrzyniak, s. 133-142.

Wojtyła K., Osoba i czyn oraz inne studia antropologiczne, Lublin 2000.

Zych A., Człowiek wobec starości, Katowice 1999.

\section{Fr. Józef Młyński: Seniors activity in the local environment}

\section{Summary}

Senior policy appears as a significant challenge for the present. Sociologists and demographers constantly emphasize that Polish society is aging. Therefore, there is a great need to stimulate the activities of local social policy for the elderly and seniors.

The purpose of this article is to show social and educational activity of seniors in the local community. The analysis shows that seniors participate in organized forms of activity: Universities of the Third Age, clubs of seniors, councils of seniors, in parish Caritas, various associations, voluntary work and other public benefit institutions. It should be added that it is easier to activate seniors living in urban environments than rural areas. In addition, this article also presents the role of a social worker as a leader-moderator of the local community responsible for stimulating social and educational activity of seniors.

Keywords: senior policy, senior, social and educational activity, local government, local environment, social worker. 